\title{
Positive predictive values of $\geq 5 \%$ in primary care for cancer: systematic review
}

\author{
Mark Shapley, Gemma Mansell, Joanne L Jordan and Kelvin P Jordan
}

\begin{abstract}
Background

The positive predictive value (PPV) for cancer of symptoms, signs, and non-diagnostic test results of patients routinely consulting a GP (unselected primary care populations) can help to determine when malignancy should be excluded. Comparisons with other illness indicate that a value of $5 \%$ or more may
\end{abstract} be regarded as highly predictive.

Aim

To identify symptoms, signs, and non-diagnostic test results in unselected primary care populations that are highly predictive of cancer.

Design of study

Systematic review.

Setting

Primary care.

Method

Fourteen bibliographic databases were searched, using terms for primary care, cancer, and predictive values. Reference lists of relevant papers were hand-searched Data were extracted and the quality of each paper was assessed using predefined criteria, and checked by a second reviewer.

\section{Results}

Twenty-five studies were identified. PPVs of $5 \%$ or more in specific age and sex groups were reported for: rectal bleeding, change in bowel habit, and iron deficiency anaemia and colorectal cancer; haematuria and urological cancer; malignant rectal examination and prostate cancer; haemoptysis and lung cancer; dysphagia and oesophageal cancer; breast lump and breast cancer; and postmenopausal bleeding and gynaecological cancer.

Conclusion

Robust evidence was found for eight symptoms, signs, and non-diagnostic test results as strongly indicative of cancer for specific age and sex groups in unselected primary care populations. These have the potential to improve the early diagnosis of some cancers in primary care by the use of computer warning flags, improved guidelines, audit, and appraisal.

Keywords

cancer; positive predictive values; predictive value of tests; primary care.

\section{INTRODUCTION}

When a patient consults a GP, part of the management of the individual involves an assessment of the probability of serious illness including malignancy. One way of expressing this probability is in terms of the positive predictive value (PPV): the proportion of people with the symptom, sign, or test result who develop cancer. Research on medical decision models reveals that probabilities and the valuation of outcomes are distorted by individuals, ${ }^{1}$ and thus theories of behaviour based on cognitive assessment of risk are not directly applicable to the consultation. ${ }^{2}$ For instance, in one model of the consultation, the 'evidence' from research that allows the calculation of probabilities of risk and benefit is modified by an individual doctor's knowledge, skills, attitudes, resources, and legal requirements, and an individual patient's ideas, concerns, expectations, beliefs, and values, to produce the final outcome. ${ }^{3}$ These factors vary widely between individuals.

Decision makers who wish to maximise desirable outcome often adopt models based on probabilities of benefits and harms. Predictive values have been incorporated into guidelines for primary care published by various colleges, academies, and institutes, including the National Institute for Health and Clinical Excellence, ${ }^{4}$ concerning who to investigate or refer for possible malignancy in primary care. A major criticism

M Shapley, DM, FRCGP, GP and senior research fellow; G Mansell, MSc, research assistant; JL Jordan, MSc, MA, research information manager; $\mathbf{K} \boldsymbol{P}$ Jordan, $\mathrm{PhD}$, reader in biostatistics, Primary Care Sciences, Keele University.

Address for correspondence

Dr Mark Shapley, Arthritis Research UK Primary Care Centre, Primary Care Sciences, Keele University, Keele, ST5 5BG. E-mail: mark.shapley@northstaffs.nhs.uk

Submitted: 16 June 2010; Editor's response: 29 June 2010; final acceptance: 19 July 2010.

(C)British Journal of General Practice

This is the full-length article of an abridged version published in print. Cite this article as: Br J Gen Pract 2010; DOI: 10.3399/bjgp10X515412. 
is that much of the evidence that underpins these guidelines is not derived from those patients who consult a GP during a routine consultation. ${ }^{5}$ This is important, because predictive values are dependent on the prevalence of the disease in the population from which they are derived and thus applied. The prevalence of cancers within populations and their associated PPVs of symptoms, signs, and nondiagnostic test results increase from community to primary care to hospital populations.

The level of the predictive value given in guidelines at which action is required to investigate or not for cancer will depend on the consequences of a delay in the diagnosis of the disease and the physical, psychological, and material cost of investigation. No guidelines for cancer have been published that state the level of risk that necessitates action. NICE guidelines for the primary prevention of cardiovascular disease recommend statin therapy for hyperlipidaemia when the 10 -year cardiovascular risk is $20 \%$ or more. ${ }^{6}$ This threshold for initiating statin therapy was based on a cost-effectiveness analysis and risk of adverse effects. Studies show a reduction in relative risk of $27 \%$ (95\% confidence interval $[\mathrm{Cl}]=14$ to $37 \%$ ) from statin therapy in patients without cardiovascular disease. This equates to an absolute risk reduction of approximately $5 \%$ or a number needed to treat with statins to prevent a cardiovascular event of 20. Statins are a safe group of drugs with a low risk of serious adverse effects at standard doses (less than 1 in 10000 patient-years for myopathy). ${ }^{7}$ The consequences of delayed cancer diagnosis in terms of morbidity and mortality are comparable to those of cardiovascular disease, and generally the risks of cancer investigation are similar to the risk of statin therapy. For instance, the rate of perforation of the bowel for colonoscopy used in the investigation for colorectal cancer is 1:769 and procedure-related mortality $1: 1537 .{ }^{8}$

Fear of cancer may mean it is perceived by patients as a greater risk than cardiovascular disease, even though a greater number of people die of the latter. ${ }^{1}$ Emotional reactions to risky situations often diverge from cognitive assessments of those risks. ${ }^{2}$ While the level of risk an individual should take cannot be defined, comparison of risk of cancer to that of cardiovascular disease suggests that if a population consults with a symptom that could be cancer, then the maximum acceptable risk of not excluding cancer is 1 in 20, which equates to a PPV of $5 \%$.

The objective of this systematic review was to identify the symptoms, signs, and non-diagnostic test results in people routinely consulting a GP that have a PPV of $5 \%$ or more for cancer and hence mandate action by a GP except in individual patient-centred circumstances.

\section{How this fits in}

The positive predictive values of symptoms, signs, and non-diagnostic test results for cancer in primary care are generally low. The level of risk for cancer that a patient and doctor are willing to accept varies. Using systematic review, good evidence has been gathered for eight symptoms, signs, and non-

diagnostics test results as being highly predictive of cancer in primary care.

Recommendations for clinical practice, audit, education, and research are made.

\section{METHOD}

\section{Search strategy}

Fourteen electronic databases were searched from their commencement to October 2009 (Box 1), using terms for primary care, cancer, and predictive values. Searches were limited to English language and human studies. The search strategy used in MEDLINE is shown in Box 2.

Reference lists of relevant studies were checked and citations were tracked using electronic databases. Experts in the field were emailed for further information. All the references were downloaded into reference management software, and the duplicates were removed.

\section{Inclusion and exclusion criteria}

Primary studies on unselected primary care populations (patients who consult a GP during a routine consultation) that examined symptoms, signs, or tests for a possible cancer were included in the review. The study had to report a PPV for the symptom, sign, or test, or contain the information necessary to calculate it. For final inclusion, the presented or

\section{Box 1. Electronic databases searched.}

- MEDLINE (from 1950)

- EMBASE (1980)

- Cumulative Index to Nursing and Allied Health Literature (CINAHL) (1981)

- Web of Science (1970)

- Biosis Previews (1969)

- Ageline (1978)

- Applied Social Sciences Index and Abstracts (1987)

- Biological Sciences Health and Safety Abstracts (1981)

- Social Services Abstracts (1979)

- Sociological Abstracts (1952)

- Academic Search Elite (1975)

- British Nursing Index (2004)

- International Bibliography of the Social Sciences (1919)

- Health Management Information Consortium (1919) 


\section{Box 2. Search (example taken from search used for the MEDLINE database).}

"“GP"” OR exp† FAMILY PRACTICE OR exp. PHYSICIANS, FAMILY OR exp. PRIMARY HEALTH CARE OR (family ADJ2 $\ddagger$ practi ${ }^{\star}$ ) OR (general ADJ2 practi*) OR (primary ADJ2 care) OR (family ADJ (physician OR doctor $\left.\left.{ }^{\star}\right)\right)^{\prime \prime}$

AND

"exp. NEOPLASMS OR neoplasm* OR cancer ${ }^{*}$ OR carcinoma* OR malignan* OR lesion* OR tumo?§r"

AND

"(risk* ADJ3 cancer) OR "PPV" OR (predictive ADJ value ${ }^{\star}$ ) OR (diagnos ${ }^{\star}$ ADJ value*) OR (early ADJ diagnosis) OR (conditional ADJ probabilit*) OR sensitivity OR specificity OR predictor* OR prevalen* OR (time ADJ interval) OR inciden* OR exp "REFERRAL AND CONSULTATION" OR alarm features"

* truncation - picks up various different word endings. $\dagger$ exp. $=$ exploded thesaurus term: picks up all articles which contain the particular terms as a keyword. $\ddagger A D J=$ adjacent: picks up words next to each other in a document (ADJ3 = picks up words which have up to 3 words in between them). $\S ?$ ? picks up alternative spellings

calculated PPV had to be:

- $5 \%$ or more either for the whole study population or for an age/sex stratum; or

- less than $5 \%$ but for the same symptom, sign, or test another eligible study gave a point estimate for the PPV of $5 \%$ or more.

The latter criterion was necessary in order to calculate a pooled PPV using all the evidence for a symptom, sign, or test and to compare studies with conflicting results. Exclusion criteria for the review were:

- screening studies, as these involve asymptomatic individuals;

- tests in which a histological diagnosis could be made, as clinical judgement on the need for further investigation or referral would be removed (for example, endoscopy with biopsy, skin biopsy);

- metastatic, recurrent, or cancer-therapy studies as these are not early disease;

- studies with 15 cases or fewer, as these are unlikely to produce reliable conclusions;

- studies written in non-English language due to lack of resources for translating papers; and

- studies in healthcare systems that are not comparable to the UK.

\section{Study selection and assessment of methodological quality}

One reviewer screened titles and abstracts and retrieved papers for inclusion. A second reviewer checked $150(7 \%)$ of the abstracts and $25 \%$ of the full papers to ensure they met the eligibility criteria. All studies identified in the screening of titles and abstracts that met the eligibility criteria, or for which it was not possible to tell, were retrieved in full. Two authors independently carried out an unblinded assessment of the risk of bias in each eligible study, using the Newcastle-Ottawa Quality Assessment Scales (NOQAS), ${ }^{9}$ for cohort and case-control studies. Studies are rated from 1 to 9 stars in the NOQAS, with 9 stars indicating a high-quality study. Any discrepancies or disagreements were discussed, and if consensus could not be achieved this was resolved by a third reviewer.

\section{Data extraction and analysis}

Once the final selection of articles for inclusion had been agreed, two researchers independently extracted data using a standardised data-extraction form. This included the type of study, characteristics of the study participants, the duration of follow-up, and the reported or calculated PPV.

Any subgroups (age and/or sex) reported in the studies that contained fewer than 15 people, or where authors stated that numbers were too low to reasonably calculate a $\mathrm{Cl}$ and could not be combined with other data, were excluded from the review.

In studies that did not report the PPV, it was calculated as the proportion of those with that symptom, sign, or test who developed cancer. Where 95\% Cls for the PPV were not stated in the paper, these were estimated, where possible, using the data presented. Where this was not possible, an attempt was made to contact the authors.

A meta-analysis was performed to obtain a pooled PPV for symptoms reported in four or more studies. The $I^{2}$ statistic was first calculated to assess the heterogeneity of the studies examining a symptom. The $\mathrm{I}^{2}$ statistic can be interpreted as the proportion of total variation in study estimates that is due to heterogeneity between studies. ${ }^{10}$ For risk factors where studies could be considered homogenous, a metaanalysis using a fixed-effects (no significant interstudy variation) approach was used. Otherwise, a randomeffects approach (significant interstudy variation) based on the inverse variance method was used. ${ }^{10}$

The analysis was performed using Stata (version 10) and confidence interval analysis software. ${ }^{11}$

\section{RESULTS}

The search resulted in 17889 unique references. Of these, 25 papers were found to meet all the eligibility criteria (Figure 1).

Sixteen of the included studies were conducted in the UK, two in each of the Netherlands, Belgium, and US, and one in each of Australia, Denmark, and Germany.

Recruitment into the studies was by one of three 


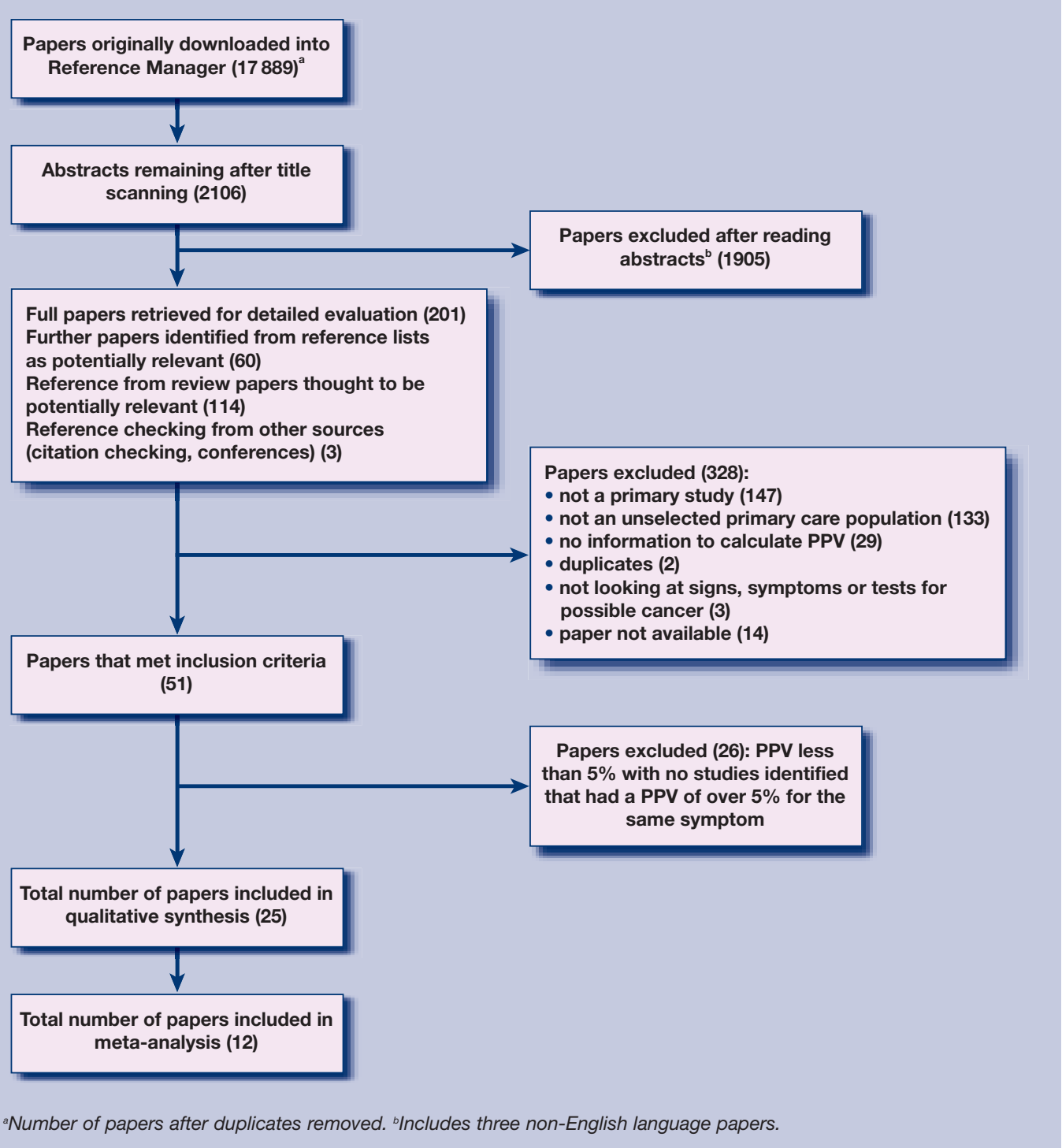

Figure 1. Results of search strategy and selection procedure.

processes: retrospective analysis of clinical records, recruitment of patients with symptoms by GPs either as part of routinely collected data or specifically for the study, and postal survey with prospective identification of cancer from GP records.

Studies varied in the method of extraction of medical record data. The source of medical record data was either routinely coded data only, all routinely recorded data including free text, or GP registered onto specific doctor-completed forms. The duration of follow-up when it was reported ranged from no follow-up to 11 years. Five studies reported that cancer was excluded prior to the first consultation.

Nineteen of the studies had a score of $\geq 6$ on the NOQAS, indicating good quality. Common flaws were: the cohort was unrepresentative of unselected primary care populations; differences in criteria determining the presence of cancer; incomplete or inadequate blinding of assessment; lack of demonstration that the individual had not had the relevant cancer diagnosed previously; short duration of follow-up; and loss to follow-up.

\section{Cancer site}

Gastrointestinal. For colorectal cancer, 12 studies were identified giving a predictive value of $5 \%$ or more, and three further studies were identified giving a value of less than $5 \%$ for one of the symptoms or combinations of symptoms. In 11 of the studies, rectal bleeding (definitions varied) had a predictive value of $5 \%$ or more in at least one of the age-sex stratifications (Table 1). ${ }^{12-22}$ Eight of these had quality scores of $\geq 6$.

In seven of the 11 studies there was, however, potential selection bias as GPs recruited participants into the study. In three it was stated that participants may not have been representative of all those consulting with the symptom, ${ }^{18,20,21}$ and in two studies it was demonstrated that the effect of this potential bias was not significant. ${ }^{16,17}$ In three additional studies, rectal bleeding had a PPV of less than $5 \%$ in all the 
Table 1. Studies giving a PPV of $\geq 5 \%$ in one or more strata of rectal bleeding for colorectal cancer.

\begin{tabular}{|c|c|c|c|c|c|c|c|c|c|c|}
\hline \multirow[b]{2}{*}{$\begin{array}{l}\text { Study and NOQAS } \\
\text { star rating }\end{array}$} & \multirow[b]{2}{*}{ IS Type } & \multirow[b]{2}{*}{$\begin{array}{l}\text { Data } \\
\text { source }\end{array}$} & \multirow[b]{2}{*}{ Follow-up } & \multirow[b]{2}{*}{ Age, years } & \multirow[b]{2}{*}{ Sex } & \multirow[b]{2}{*}{ Symptom } & \multicolumn{4}{|c|}{ Stratification with PPV $\geq 5 \%$} \\
\hline & & & & & & & Sex & Age, years & $\begin{array}{l}\text { Number witl } \\
\text { symptom }\end{array}$ & $\begin{array}{l}\text { th PPV, } \\
\%(95 \% \mathrm{Cl})\end{array}$ \\
\hline \multirow{3}{*}{$\begin{array}{l}\text { Jones et al, } \\
2007^{12} \text { (9 stars) }\end{array}$} & \multirow{3}{*}{$\begin{array}{l}\text { Retrospective } \\
\text { cohort } \\
\text { cc }\end{array}$} & \multirow{3}{*}{$\begin{array}{l}\text { Routinely } \\
\text { recorded } \\
\text { omputer codes }\end{array}$} & \multirow{3}{*}{3 years } & \multirow[t]{3}{*}{$\geq 15$} & \multirow[t]{3}{*}{ All } & \multirow{3}{*}{$\begin{array}{c}\text { Rectal } \\
\text { bleeding } \\
\text { computer codes }\end{array}$} & \multirow[t]{2}{*}{ M } & $75-84$ & 633 & 7.7 (5.8 to 10.1$)$ \\
\hline & & & & & & & & $\geq 85$ & 157 & 5.1 (2.2 to 9.8$)$ \\
\hline & & & & & & & $\mathrm{F}$ & $75-84$ & 930 & 7.2 (5.6 to 9.1$)$ \\
\hline $\begin{array}{l}\text { Parker et al, } \\
2007^{13} \text { (7 stars) }\end{array}$ & $\begin{array}{l}\text { Retrospective } \\
\text { cohort }\end{array}$ & $\begin{array}{l}\text { Routinely } \\
\text { recorded } \\
\text { computer } \\
\text { codes }\end{array}$ & 2 years & $\geq 25$ & All & $\begin{array}{l}\text { First ever } \\
\text { consultation with } \\
\text { rectal bleeding } \\
\text { computer code }\end{array}$ & $\mathrm{M}+\mathrm{F}$ & $75-84$ & \multicolumn{2}{|c|}{$\begin{array}{l}\text { Number } 5.5 \text { ( } 4.7 \text { to } 6.3) \\
\text { with cancer } \\
173\end{array}$} \\
\hline \multirow{3}{*}{$\begin{array}{l}\text { Lawrenson et al, } \\
2006^{14} \text { (9 stars) }\end{array}$} & \multirow{3}{*}{$\begin{array}{l}\text { Retrospective } \\
\text { cohort } \\
\text { cc }\end{array}$} & \multirow{3}{*}{$\begin{array}{l}\text { Routinely } \\
\text { recorded } \\
\text { omputer codes }\end{array}$} & \multirow{3}{*}{$\begin{array}{l}1 \text { year } \\
\text { s }\end{array}$} & \multirow[t]{3}{*}{$40-89$} & \multirow[t]{3}{*}{ All } & Rectal bleeding & M & $60-69$ & Not given & $6.0^{\mathrm{a}}$ \\
\hline & & & & & & & & $70-79$ & Not given & $7.7^{\mathrm{a}}$ \\
\hline & & & & & & & & 80-89 & Not given & $9.1^{\mathrm{a}}$ \\
\hline Wauters et al, & Retrospective & Routinely & $18-30$ & All & All & Cases of & $\mathrm{M}+\mathrm{F}$ & $60-69$ & 711 & 11.2 (5.0 to 21.0 ) \\
\hline $2000^{15}$ (6 stars) & & & months & & & rectal bleeding & & $70-79$ & $66 \quad 2$ & 21.2 (12.0 to 33.0$)$ \\
\hline & & & & & & & & $\geq 80$ & 51 & 5.8 (1.2 to 16.2$)$ \\
\hline Du Toit et al, & Prospective & Specifically & Not given & $\geq 45$ & All & New onset & $\mathrm{M}+\mathrm{F}$ & $65-74$ & 63 & 9.5 (4.4 to 19.3$)$ \\
\hline $2006^{16}$ (6 stars) & cohort & registered & & & & rectal bleeding & & $\geq 75$ & 76 & 7.9 (3.7 to 16.2$)$ \\
\hline $\begin{array}{l}\text { Heintze et al, } \\
2005^{17} \text { (7 stars) }\end{array}$ & $\begin{array}{c}\text { Prospective } \\
\text { cohort }\end{array}$ & $\begin{array}{l}\text { Specifically } \\
\text { registered }\end{array}$ & Not given & $\geq 15$ & All & $\begin{array}{c}\text { Cases rectal } \\
\text { bleeding }\end{array}$ & $\mathrm{M}+\mathrm{F}$ & $\geq 50$ & 268 & $5.6(3.4$ to 9.0$)$ \\
\hline $\begin{array}{l}\text { Ellis and } \\
\text { Thompson, } \\
2005^{18}(6 \text { stars })\end{array}$ & $\begin{array}{l}\text { Prospective } \\
\text { cohort }\end{array}$ & $\begin{array}{l}\text { Specifically } \\
\text { registered }\end{array}$ & 18 months & $>34$ & All & $\begin{array}{c}\text { Primary } \\
\text { complaint } \\
\text { rectal bleeding }\end{array}$ & $\mathrm{M}+\mathrm{F}$ & $\geq 60$ & 155 & 5.2 (2.6 to 9.9$)$ \\
\hline $\begin{array}{l}\text { Nørrelund and } \\
\text { Nørrelund, } \\
1996^{19}(3 \text { stars) }\end{array}$ & $\begin{array}{l}\text { Prospective } \\
\text { cohort }\end{array}$ & $\begin{array}{l}\text { Specifically } \\
\text { registered }\end{array}$ & $\begin{array}{l}22-57 \\
\text { months }\end{array}$ & $\geq 40$ & All & $\begin{array}{l}\text { First episode or } \\
\text { change in rectal } \\
\text { bleeding pattern }\end{array}$ & $\mathrm{M}+\mathrm{F}$ & $\geq 40$ & 3641 & 14.8 (11.6 to 18.9$)$ \\
\hline $\begin{array}{l}\text { Metcalf et al, } \\
1996^{20}(5 \text { stars })\end{array}$ & $\begin{array}{c}\text { Prospective } \\
\text { cohort }\end{array}$ & $\begin{array}{l}\text { Specifically } \\
\text { registered }\end{array}$ & Not given & $\geq 40$ & All & $\begin{array}{l}\text { Rectal bleeding } \\
\text { of recent onset }\end{array}$ & $\mathrm{M}+\mathrm{F}$ & $\geq 40$ & 99 & $8.1(4.2$ to 15.1$)$ \\
\hline $\begin{array}{l}\text { Mant et al, } \\
\left.1989^{22} \text { ( } 5 \text { stars }\right)\end{array}$ & $\begin{array}{c}\text { Prospective } \\
\text { cohort }\end{array}$ & $\begin{array}{l}\text { Specifically } \\
\text { registered }\end{array}$ & Not given & $\geq 40$ & All & $\begin{array}{l}\text { Rectal bleeding } \\
<6 \text { months onset }\end{array}$ & $\mathrm{M}+\mathrm{F}$ & $\geq 40$ & 1451 & 11.0 (6.9 to 17.2$)$ \\
\hline Fijten et al, & Prospective & Specifically & Mean & $18-75$ & All & Overt rectal & $\mathrm{M}$ & $18-75$ & 118 & 5.9 (2.9 to 11.7$)$ \\
\hline 15 & entive & & $\begin{array}{l}20 \text { months } \\
\text { SD } 5 \text { months }\end{array}$ & & & $\begin{array}{l}\text { bleeding reason for } \\
\text { encounter or history } \\
\text { of rectal blood loss } \\
\text { jisible to the patient in } \\
\text { he previous } 3 \text { months }\end{array}$ & $\mathrm{M}+\mathrm{F}$ & $60-75$ & $40 \quad 2$ & 20.0 (10.5 to 34.8$)$ \\
\hline
\end{tabular}

${ }^{a}$ Not possible to calculate confidence intervals (author contacted, original data not available). $F=$ female. $M=$ male. NOQAS $=$ Newcastle-Ottawa Quality Assessment Scales. PPV = positive predictive value. $S D=$ standard deviation.

subgroups presented (Table 2). ${ }^{23-25}$ One study ${ }^{19}$ provided separate results for new and old symptoms with the former having a PPV of greater than $5 \%$ and the latter less than $5 \%$.

A meta-analysis of studies concerning rectal bleeding is shown in Figures 2 and 3. One study was excluded as the original data were unavailable, ${ }^{14}$ and one due to ambiguous data. ${ }^{25}$ Heterogeneity measured by the $\mathrm{I}^{2}$ statistic was high $\left(\mathrm{I}^{2}=93 \%\right.$ for studies of older adults), and more recent studies (which were of higher quality) appear to give lower PPVs. The pooled PPV for older adults for rectal bleeding was $4.57 \%(95 \% \mathrm{Cl}=$ 3.68 to 5.46 ), and exceeded $5 \%$ in those patients aged $\geq 70$ years $(5.54 \% 95 \% \mathrm{Cl}=3.91$ to 7.17$)$, although the $\mathrm{Cl}$ crosses $5 \%$ indicating some uncertainty (Figure 3).

There were two studies (both high quality) that identified patients from large electronic databases with a computer code of change in bowel habit in the medical record and used no free text. In a retrospective cohort study, Lawrenson et al reported a PPV of more than $5 \%$ in men aged $\geq 60$ years for colorectal cancer, ${ }^{14}$ while Hamilton and co-workers, in a case-control study, reported PPVs of less than 5\% for all age groups (Table 3). ${ }^{24}$

In two prospective cohort studies, ${ }^{18,21}$ and a randomised controlled trial, ${ }^{26}$ the symptom of rectal bleeding was combined with other symptoms or test results to give PPVs of $5 \%$ or more (Table 4). However, the numbers of symptomatic patients were generally low and Cls wide. Any conclusions drawn from these findings are weak. An additional case-control study gave some combinations of symptoms and signs a 
Table 2. Studies giving a PPV of $<5 \%$ of rectal bleeding for colorectal cancer.

\begin{tabular}{|c|c|c|c|c|c|c|c|c|}
\hline $\begin{array}{l}\text { Study and NOQAS } \\
\text { star rating }\end{array}$ & Type & Data & Follow-up & Age, years & Sex & $\begin{array}{l}\text { Number with } \\
\text { symptom }\end{array}$ & Symptom & Comments \\
\hline $\begin{array}{l}\text { Hamilton et al, } \\
2009^{24} \text { (8 stars) }\end{array}$ & Case-control & $\begin{array}{l}\text { Routinely recorded } \\
\text { computer codes }\end{array}$ & NA & $\geq 30$ & $\mathrm{M}+\mathrm{F}$ & $\begin{array}{l}853 \text { cases, } \\
460 \text { controls }\end{array}$ & $\begin{array}{l}\text { Rectal bleeding } \\
\text { computer codes }\end{array}$ & $\begin{array}{l}\text { PPV stratified by } \\
\text { age and sex but } \\
\text { numbers of cases } \\
\text { and controls by age } \\
\text { and sex not given }\end{array}$ \\
\hline $\begin{array}{l}\text { Thompson et al, } \\
1999^{25} \text { (3 stars) }\end{array}$ & $\begin{array}{l}\text { Prospective } \\
\text { cohort }\end{array}$ & $\begin{array}{l}\text { Self-reported } \\
\text { questionnaire }\end{array}$ & $4-5$ years & $>16$ & $\mathrm{M}+\mathrm{F}$ & 197 & $\begin{array}{l}\text { Rectal bleeding } \\
\text { and consulted GP }\end{array}$ & $\begin{array}{c}\text { No cases of rectal } \\
\text { cancer; two cases } \\
\text { of caecal cancer felt } \\
\text { not to cause bleeding } \\
\text { but not stated if in } \\
\text { consultation cohort }\end{array}$ \\
\hline $\begin{array}{l}\text { Nørrelund and } \\
\text { Nørrelund,1996 } \\
\text { (3 stars) }\end{array}$ & $\begin{array}{l}\text { Prospective } \\
\text { cohort }\end{array}$ & $\begin{array}{l}\text { Specifically } \\
\text { registered }\end{array}$ & 22-57 months & $\geq 40$ & $\mathrm{M}+\mathrm{F}$ & 45 & $\begin{array}{l}\text { Current bleeding } \\
\text { episode similar } \\
\text { to previous }\end{array}$ & $\begin{array}{c}\text { PPV } 4.4 \% \\
(95 \% \mathrm{Cl}=1.2 \text { to } 14.8)\end{array}$ \\
\hline
\end{tabular}

$F=$ female. $M=$ male. $N A=$ not applicable. NOQAS $=$ Newcastle-Ottawa Quality Assessment Scales. PPV = positive predictive value.

PPV above 5\%, but the authors did not calculate Cls for PPVs due to small sample sizes. ${ }^{23}$

One study was identified evaluating iron deficiency anaemia as a predictor for upper and lower gastrointestinal cancer, ${ }^{27}$ one for cancer, ${ }^{28}$ and one for colorectal cancer only (Table 5). ${ }^{29}$ The study by Yates et al identified 71 patients with cancer from a cohort of 431 people with iron deficiency anaemia..$^{28}$ Of these, 35 had lower gastrointestinal cancer, 23 non-gastrointestinal cancer, and 13 other gastrointestinal cancer. The PPV for colorectal cancer was above $5 \%$ in men aged $>20$ years with a haemoglobin of $\leq 12 \mathrm{~g} / \mathrm{dll}$, and the PPV was less than $5 \%$ in women aged $>50$ years with a haemoglobin of $\leq 11 \mathrm{~g} / \mathrm{dl}$. Hamilton et al used a casecontrol methodology but felt unable to calculate a PPV for colorectal cancer in men aged 30 to 59 years, as sample sizes were small. ${ }^{29}$ Only in cohorts aged $\geq 60$ years did the PPV become greater than $5 \%$, although in some strata the PPV was less than $5 \%$. Stellon and Kenwright studied all patients aged $>50$ years, where they found the PPV of iron deficiency anaemia for colorectal cancer to be greater than $5 \%{ }^{27}$

Urological. Three high-quality studies examined symptoms of urological cancer (Table 6). One of these studies excluded prostate cancer, ${ }^{12}$ one concerned undefined urological cancer, ${ }^{30}$ and the third only prostate cancer. ${ }^{31}$ Jones et al found PPVs in men aged $\geq 55$ years and women aged $\geq 65$ years to be greater than $5 \%$ for haematuria. ${ }^{12}$ Bruyninckx et al found macroscopic haematuria to have a PPV of over $5 \%$ in men aged $\geq 60$ years and women aged $\geq 40$ years. ${ }^{30}$ The study by Hamilton et al of prostate cancer only was a case-control design. ${ }^{31}$ They found a 'malignant rectal

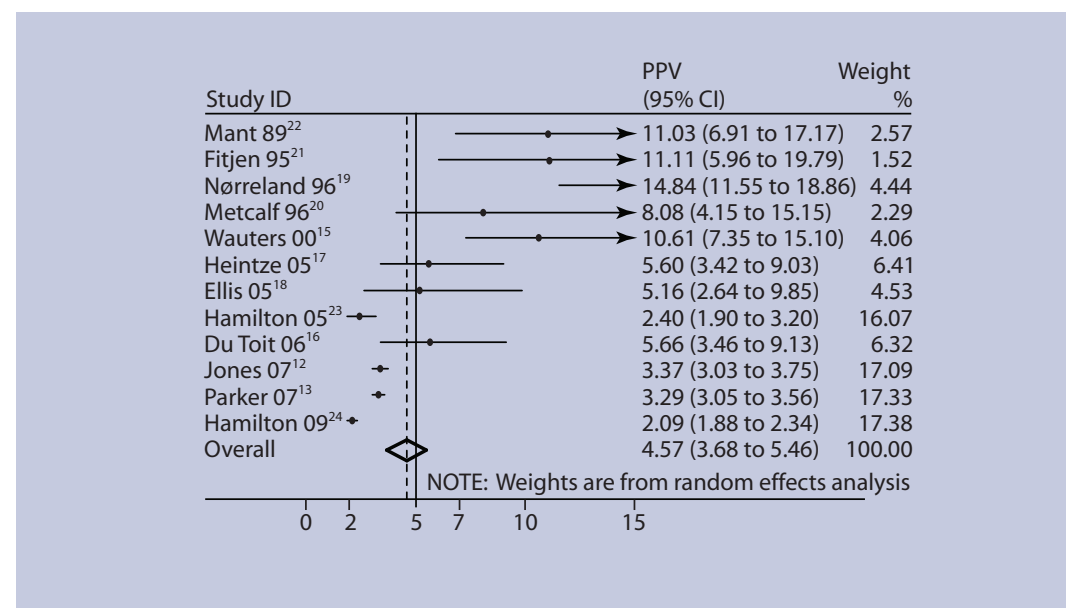

Figure 2. PPV of rectal bleeding for colorectal cancer in older adults. Age ranges for studies (years): $\geq 45$ du Toit, ${ }^{16}$ Jones, $^{12}$ Parker; ${ }^{13} \geq 60$ Ellis; ${ }^{18} \geq 50$ Wauters, ${ }^{15}$ Heintze, ${ }^{17}$ Hamilton (09) ${ }^{24} ; \geq 40$ Mant, ${ }^{22}$ Nørrelund, ${ }^{19}$ Metcalf, ${ }^{20}$ Hamilton (05),;3 50-75 Fijten. ${ }^{21}$ Figures for Hamilton $09^{24}$ were estimated from original data sent by the authors.

Figure 3. PPV of rectal bleeding for colorectal cancer age 70-75 years and over. Age ranges for studies (years): $\geq 75$ Du Toit, ${ }^{16}$ Jones, ${ }^{12}$ Parker, ${ }^{13}$ Hamilton; ${ }^{24} \geq 70$ Wauters. ${ }^{15}$ Figures for Hamilton $09^{24}$ were estimated from original data sent by the authors.

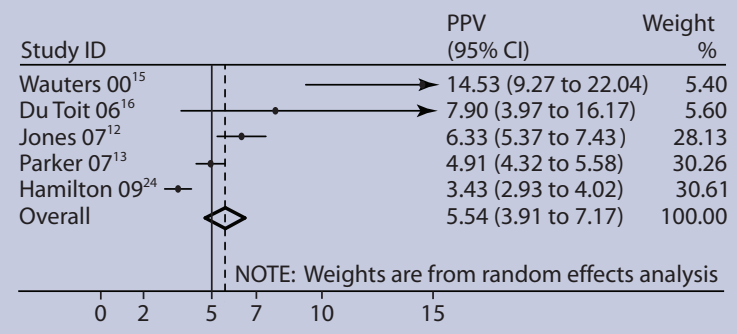


Table 3. Studies giving a PPV of $\geq 5 \%$ change in bowel habit for colorectal cancer or a predictive value of $<5 \%$ in an equivalent stratum.

\begin{tabular}{|c|c|c|c|c|c|c|c|c|c|c|}
\hline \multirow[b]{2}{*}{$\begin{array}{l}\text { Study and NOQAS } \\
\text { star rating }\end{array}$} & \multirow[b]{2}{*}{ Type } & \multirow[b]{2}{*}{$\begin{array}{c}\text { Data } \\
\text { source }\end{array}$} & \multirow[b]{2}{*}{ Follow-up } & \multirow[b]{2}{*}{ Age, years } & \multirow[b]{2}{*}{ Sex } & \multirow[b]{2}{*}{ Symptom } & \multicolumn{4}{|c|}{ Stratification with PPV $\geq 5 \%$} \\
\hline & & & & & & & Sex & Age, years & $\begin{array}{c}\text { Number with } \\
\text { symptom }\end{array}$ & $\begin{array}{c}\text { PPV, } \\
\%(95 \% \mathrm{Cl})\end{array}$ \\
\hline \multirow{2}{*}{$\begin{array}{l}\text { Lawrenson et al, } \\
2006^{14} \text { (9 stars) }\end{array}$} & \multirow{2}{*}{$\begin{array}{c}\text { Retrospective } \\
\text { cohort }\end{array}$} & \multirow{2}{*}{$\begin{array}{l}\text { Routinely } \\
\text { recorded } \\
\text { mputer codes }\end{array}$} & \multirow{2}{*}{1 year } & \multirow{2}{*}{$40-89$} & \multirow{2}{*}{$\mathrm{M}+\mathrm{F}$} & \multirow{2}{*}{$\begin{array}{c}\text { Change in } \\
\text { bowel habit } \\
\text { computer codes }\end{array}$} & \multirow{2}{*}{$\mathrm{M}$} & $70-79$ & Not given & $8.5^{\mathrm{a}}$ \\
\hline & & & & & & & & $80-89$ & Not given & $7.7^{\mathrm{a}}$ \\
\hline \multirow{3}{*}{$\begin{array}{l}\text { Hamilton et al, } \\
2009^{24} \text { (8 stars) }\end{array}$} & \multirow[t]{3}{*}{ Case-control } & \multirow{3}{*}{$\begin{array}{l}\text { Routinely } \\
\text { recorded } \\
\text { mputer codes }\end{array}$} & \multirow[t]{3}{*}{ NA } & \multirow[t]{3}{*}{$\geq 30$} & \multirow[t]{3}{*}{$\mathrm{M}+\mathrm{F}$} & \multirow{3}{*}{$\begin{array}{c}\text { Change in } \\
\text { bowel habit } \\
\text { computer codes }\end{array}$} & \multirow[t]{3}{*}{ M } & $60-69$ & \multicolumn{2}{|c|}{ Not given 3.0 (2.1 to 4.2 ) } \\
\hline & & & & & & & & $70-79$ & \multicolumn{2}{|c|}{ Not given 4.2 (3.2 to 5.4} \\
\hline & & & & & & & & 80-89 & \multicolumn{2}{|c|}{ Not given 3.9 (2.8 to 5.5 ) } \\
\hline
\end{tabular}

${ }^{a}$ Not possible to calculate confidence intervals (author contacted original data not available). $F=$ female. $M=$ male. NA =not applicable. NOQAS $=$ NewcastleOttawa Quality Assessment Scales. PPV = positive predictive value.

examination' to have a PPV of greater than 5\% for prostate cancer. Some combinations of symptoms had a PPV above $5 \%$ for prostate cancer, but the authors did not calculate Cls for PPVs, because of small sample sizes.

Lung. One study identified haemoptysis as having a PPV of $5 \%$ or more for lung cancer, ${ }^{12}$ and another study resulted in a PPV for this symptom of less than $5 \%$ (Table 7). ${ }^{32}$ In the latter study, haemoptysis in combination with other symptoms, or recurrent haemoptysis, had high predictive values. However, the authors did not calculate Cls due to small sample sizes. Jones et al used only computer codes to identify the symptom, ${ }^{12}$ while Hamilton et al used codes and free text. ${ }^{32}$ Both studies were high quality.

Oesophageal. Two studies (one high and one low quality) were identified for oesophageal cancer (Table 8). ${ }^{12,33}$ No studies were identified that gave a PPV of less than $5 \%$ for the symptom of dysphagia.

Breast. Two studies (one high quality) identified a breast lump symptom, ${ }^{34,35}$ and one high-quality study a clinician-palpable breast lump, ${ }^{36}$ as having a PPV of $5 \%$ or more for breast cancer (Table 9). No studies were identified that gave a PPV of less than $5 \%$ for this symptom or sign. Two of the studies included all women, ${ }^{34,36}$ even though breast cancer in those aged $<20$ years is exceptionally rare..$^{37}$

Gynaecological. One high-quality retrospective study, using routinely recorded computer codes in the medical records, ${ }^{13}$ identified the first ever consultation for postmenopausal bleeding in women aged 75 to 84 years as having a PPV for relevant cancer of $5.4 \%$

\section{Table 4. Studies giving a PPV of $\geq 5 \%$ in one or more strata of rectal bleeding with another symptom for} colorectal cancer.

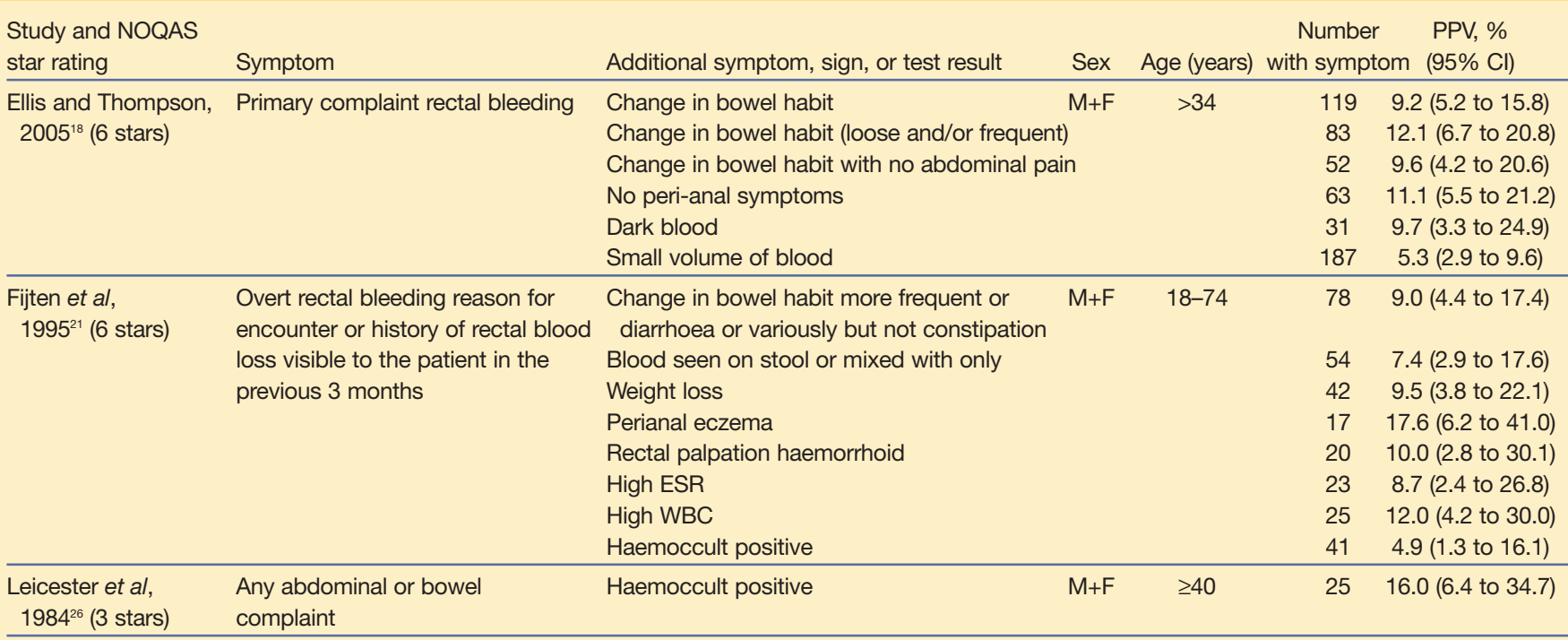

ESR = erythrocyte sedimentation rate. $F=$ female. $M=$ male. $W B C=$ white cell count. NOQAS $=$ Newcastle-Ottawa Quality Assessment Scales. PPV $=$ positive predictive value. 


\begin{tabular}{|c|c|c|c|c|c|c|c|c|c|c|}
\hline \multirow[b]{2}{*}{$\begin{array}{l}\text { Study and NOQAS } \\
\text { star rating }\end{array}$} & \multirow[b]{2}{*}{ S Type } & \multirow[b]{2}{*}{$\begin{array}{l}\text { Data } \\
\text { source }\end{array}$} & \multirow[b]{2}{*}{ Follow-up } & \multirow[b]{2}{*}{ Age, years } & \multirow[b]{2}{*}{ Sex } & \multirow[b]{2}{*}{ Symptom } & \multicolumn{4}{|c|}{ Stratification with PPV } \\
\hline & & & & & & & Sex & Age, years & $\begin{array}{c}\text { Number wit } \\
\text { symptom }\end{array}$ & $\begin{array}{l}\text { vith PPV, } \\
\text { n \% }(95 \% \mathrm{Cl})\end{array}$ \\
\hline $\begin{array}{l}\text { Stellon et al, } \\
1997^{27} \text { (6 stars) }\end{array}$ & $\begin{array}{c}\text { Prospective } \\
\text { cohort }\end{array}$ & $\begin{array}{l}\text { Specifically } \\
\text { registered }\end{array}$ & Not given & $>50$ & $\mathrm{M}+\mathrm{F}$ & $\begin{array}{c}\mathrm{Hb}<12.0 \text { and/or } \\
\mathrm{MCV}<80 \text { with } \\
\text { ferritin } \leq 16\end{array}$ & $\mathrm{M}+\mathrm{F}$ & $>50$ & 26 & 7.7 (2.1 to 24.1$)$ \\
\hline \multirow[t]{2}{*}{$\begin{array}{l}\text { Yates et al, } \\
2004^{28} \text { (6 stars) }\end{array}$} & $\begin{array}{l}\text { Retrospective } \\
\text { cohort r }\end{array}$ & $\begin{array}{l}\text { e Routinely } \\
\text { recorded data }\end{array}$ & 1 year & $>20$ & M & $\begin{array}{c}\mathrm{Hb} \leq 12 \mathrm{MCV} \\
<\text { hospital normal } \\
\text { range, } \mathrm{RBC}<5.5\end{array}$ & M & $>20$ & 1541 & 17.5 (12.3 to 24.3 ) \\
\hline & & & & $>50$ & $\mathrm{~F}$ & $\begin{array}{c}\mathrm{Hb} \leq 11 \mathrm{MCV} \\
<\text { hospital normal } \\
\text { range, } \mathrm{RBC}<5.5\end{array}$ & $\mathrm{~F}$ & $>50$ & 277 & $3.2(1.7$ to 6.1$)$ \\
\hline \multirow[t]{5}{*}{$\begin{array}{l}\text { Hamilton et al, } \\
2008^{29} \text { (9 stars) }\end{array}$} & $\begin{array}{r}\text { Case-control } \\
\text { el }\end{array}$ & $\begin{array}{l}\text { Routinely } \\
\text { recorded } \\
\text { electronic data }\end{array}$ & NA & $\geq 30$ & $\mathrm{M}+\mathrm{F}$ & $\begin{array}{c}\text { Hb } 11.0-11.9 \text { with } \\
\text { indicators of iron } \\
\text { deficiency }\end{array}$ & M & $60-69$ & Not given & n 6.5 (2.0 to 19$)$ \\
\hline & & & & & & $\begin{array}{l}\mathrm{Hb}<11.0 \text { with } \\
\text { indicators of iron } \\
\text { deficiency }\end{array}$ & M & $\geq 60$ & Not given & $\begin{array}{l}\text { All age bands } \\
\text { and } \mathrm{Hb} \text { levels } \\
\mathrm{PPV}>5 \text { (range } \\
5.5 \text { to } \geq 31 \text { ) }\end{array}$ \\
\hline & & & & & & & $\mathrm{F}$ & $70-79$ & Not given & $\begin{array}{c}\text { All Hb levels } \\
\text { PPV >5 (range } \\
5.9 \text { to } 10)\end{array}$ \\
\hline & & & & & & $\begin{array}{l}\mathrm{Hb}<10.0 \text { with } \\
\text { indicators of iron } \\
\text { deficiency }\end{array}$ & $\mathrm{F}$ & $\geq 80$ & Not given & $\begin{array}{c}\text { All Hb levels } \\
\text { PPV >5 (range } \\
5.7 \text { to } 10 \%)\end{array}$ \\
\hline & & & & & & $\begin{array}{c}\mathrm{Hb}<9.0 \text { with } \\
\text { indicators of iron } \\
\text { deficiency }\end{array}$ & $\mathrm{F}$ & $60-69$ & Not given & $\begin{array}{l}\text { n } \\
\text { (likelihood ratio) }\end{array}$ \\
\hline
\end{tabular}

$F=$ female. $H b=$ haemoglobin $\left(g d l^{-1}\right) . M=$ male. $M C V=$ mean corpuscular volume (fL). NA = not applicable. NOQAS = Newcastle-Ottawa Quality Assessment Scales. $P P V=$ positive predictive value. $R B C=$ red blood corpuscles.

Table 6. Studies giving a PPV of $\geq 5 \%$ in one or more strata of symptoms for urological cancer.

\begin{tabular}{|c|c|c|c|c|c|c|c|c|c|c|c|}
\hline \multirow[b]{2}{*}{$\begin{array}{l}\text { Study and NOQA } \\
\text { star rating }\end{array}$} & \multirow[b]{2}{*}{ Cancers } & \multirow[b]{2}{*}{ Type } & \multirow[b]{2}{*}{ Data } & \multirow[b]{2}{*}{ Follow-up } & \multirow[b]{2}{*}{ Age, years } & \multirow[b]{2}{*}{ Sex } & \multirow[b]{2}{*}{$\begin{array}{l}\text { Symptom } \\
\text { or sign }\end{array}$} & \multicolumn{4}{|c|}{ Stratification with PPV $\geq 5 \%$} \\
\hline & & & & & & & & Sex & Age, years & $\begin{array}{l}\text { Number with } \\
\text { symptom }\end{array}$ & $\begin{array}{l}\text { PPV, \% } \\
(95 \% \mathrm{Cl})\end{array}$ \\
\hline \multirow{7}{*}{$\begin{array}{l}\text { Jones et al, } \\
2007^{12} \text { (9 stars) }\end{array}$} & \multirow{7}{*}{$\begin{array}{c}\text { Urethra, } \\
\text { bladder, } \\
\text { ureter } \\
\text { and kidney }\end{array}$} & \multirow{7}{*}{$\begin{array}{l}\text { Retrospective } \\
\text { cohort }\end{array}$} & \multirow{7}{*}{$\begin{array}{l}\text { Routinely } \\
\text { recorded } \\
\text { computer } \\
\text { codes }\end{array}$} & \multirow{7}{*}{3 years } & \multirow[t]{7}{*}{$\geq 15$} & \multirow[t]{7}{*}{$\mathrm{M}+\mathrm{F}$} & \multirow{7}{*}{$\begin{array}{l}\text { Haematuria } \\
\text { computer codes }\end{array}$} & \multirow[t]{4}{*}{ M } & $55-64$ & 1104 & 8.5 (6.9 to 10.3$)$ \\
\hline & & & & & & & & & $65-74$ & 1517 & 11.2 (9.7 to 12.9$)$ \\
\hline & & & & & & & & & $75-84$ & 1198 & 10.3 (8.6 to 12.1$)$ \\
\hline & & & & & & & & & $\geq 85$ & 358 & $9.2(6.4$ to 12.7$)$ \\
\hline & & & & & & & & \multirow[t]{3}{*}{$\mathrm{F}$} & $65-74$ & 846 & $5.9(4.4$ to 7.7$)$ \\
\hline & & & & & & & & & $75-84$ & 688 & 6.8 (5.1 to 9.0$)$ \\
\hline & & & & & & & & & $\geq 85$ & 293 & 8.5 (5.6 to 12.3$)$ \\
\hline \multirow{3}{*}{$\begin{array}{c}\text { Bruyninckx et al, } \\
2003^{30} \text { (7 stars) }\end{array}$} & \multirow{3}{*}{$\begin{array}{l}\text { Any of the } \\
\text { urological } \\
\text { tract }\end{array}$} & \multirow{3}{*}{$\begin{array}{l}\text { Prospective } \\
\text { cohort }\end{array}$} & \multirow{3}{*}{$\begin{array}{l}\text { Routinely } \\
\text { registered }\end{array}$} & \multirow{3}{*}{$\begin{array}{l}18-30 \\
\text { months }\end{array}$} & \multirow[t]{3}{*}{ Not given } & \multirow[t]{3}{*}{$\mathrm{M}+\mathrm{F}$} & \multirow{3}{*}{$\begin{array}{c}\text { Cases } \\
\text { macroscopic } \\
\text { haematuria }\end{array}$} & M & $\geq 60$ & \multicolumn{2}{|c|}{ Not given 22.1 (15.8 to 30.1 ) } \\
\hline & & & & & & & & $\mathrm{F}$ & $40-59$ & Not given & $6.4(1.7$ to 18.6$)$ \\
\hline & & & & & & & & & $\geq 60$ & Not given & 8.3 (3.4 to 17.9$)$ \\
\hline $\begin{array}{l}\text { Hamilton et al, } \\
2006^{31} \text { (7 stars) }\end{array}$ & Prostate & Case-control & $\begin{array}{l}\text { Routinely } \\
\text { recorded } \\
\text { data } \\
\text { including } \\
\text { free text }\end{array}$ & NA & $\geq 40$ & M & $\begin{array}{l}\text { Rectal } \\
\text { examination } \\
\text { malignant }\end{array}$ & M & $\geq 40$ & $\begin{array}{l}\text { Cases } 5 \text {, } \\
\text { controls } 41\end{array}$ & $12.0(5.0$ to 37.0$)$ \\
\hline
\end{tabular}

$F=$ female. $M=$ male. $N A=$ not applicable. NOQAS $=$ Newcastle-Ottawa Quality Assessment Scales. PPV = positive predictive value.

$(95 \% \mathrm{Cl}=4.7$ to 7.1$)$ (Table 10$)$. No studies were identified that gave a PPV of less than $5 \%$ for this symptom in the age group 75 to 84 years.
Other cancers. No other studies were identified with PPVs of over $5 \%$ for symptoms, signs, or tests for other sites of cancer. 
Table 7. Studies giving a PPV of $\geq 5 \%$ in one or more strata of symptoms for lung cancer or a predictive value of $<5 \%$ in an equivalent stratum.

\begin{tabular}{|c|c|c|c|c|c|c|c|c|c|c|}
\hline \multirow[b]{2}{*}{$\begin{array}{l}\text { Study and NOQAS } \\
\text { star rating }\end{array}$} & \multirow[b]{2}{*}{ Type } & \multirow[b]{2}{*}{$\begin{array}{c}\text { Data } \\
\text { source }\end{array}$} & \multirow[b]{2}{*}{ Follow-up } & \multirow[b]{2}{*}{ Age, years } & \multirow[b]{2}{*}{ Sex } & \multirow[b]{2}{*}{ Symptom } & \multicolumn{4}{|c|}{ Stratification with PPV } \\
\hline & & & & & & & Sex & Age, years & $\begin{array}{c}\text { Number with } \\
\text { symptom }\end{array}$ & $\begin{array}{l}\text { th PPV, } \\
\%(95 \% \mathrm{Cl})\end{array}$ \\
\hline \multirow{6}{*}{$\begin{array}{l}\text { Jones et al, } \\
2007^{12} \\
\text { (9 stars) }\end{array}$} & \multirow{6}{*}{$\begin{array}{l}\text { Retrospective } \\
\text { cohort }\end{array}$} & \multirow{6}{*}{$\begin{array}{l}\text { Routinely } \\
\text { recorded } \\
\text { omputer codes }\end{array}$} & \multirow{6}{*}{3 years } & \multirow[t]{6}{*}{$\geq 15$} & \multirow[t]{6}{*}{ All } & \multirow{6}{*}{$\begin{array}{l}\text { Haemoptysis } \\
\text { computer codes }\end{array}$} & \multirow[t]{4}{*}{ M } & $55-64$ & 514 & $8.4(6.1$ to 11.1$)$ \\
\hline & & & & & & & & $65-74$ & 5521 & $14.9(12.0$ to 18.1$)$ \\
\hline & & & & & & & & $75-84$ & $393 \quad 1$ & 17.1 (13.5 to 21.1$)$ \\
\hline & & & & & & & & $\geq 85$ & 93 & 20.4 (12.8 to 30.1$)$ \\
\hline & & & & & & & \multirow[t]{2}{*}{$\mathrm{F}$} & $65-74$ & 358 & 8.4 (5.7 to 11.8$)$ \\
\hline & & & & & & & & $75-84$ & 258 & 10.5 (7.0 to 14.9$)$ \\
\hline $\begin{array}{l}\text { Hamilton et al, } \\
2005^{32} \\
\text { (9 stars) }\end{array}$ & $\begin{array}{l}\text { Case-control } \\
\qquad \mathrm{d} e\end{array}$ & $\begin{array}{l}\text { Routinely } \\
\text { recorded } \\
\text { lata including } \\
\text { free text }\end{array}$ & $\begin{array}{c}\text { Not } \\
\text { applicable }\end{array}$ & $\geq 40$ & All & $\begin{array}{l}\text { Haemoptysis as } \\
\text { a single symptom }\end{array}$ & $\mathrm{M}+\mathrm{F}$ & $\geq 40$ & $\begin{array}{c}\text { Cases } 50, \\
\text { controls } \\
19\end{array}$ & , 2.4 (1.4 to 4.1$)$ \\
\hline
\end{tabular}

$F=$ female. $M=$ male. NOQAS $=$ Newcastle-Ottawa Quality Assessment Scales. $P P V=$ positive predictive value.

Table 8. Studies giving a PPV of $\geq 5 \%$ in one or more strata of dysphagia for oesophageal cancer.

\begin{tabular}{|c|c|c|c|c|c|c|c|c|c|c|}
\hline \multirow[b]{2}{*}{$\begin{array}{l}\text { Study and NOQAS } \\
\text { star rating }\end{array}$} & \multirow[b]{2}{*}{ Type } & \multirow[b]{2}{*}{$\begin{array}{c}\text { Data } \\
\text { source }\end{array}$} & \multirow[b]{2}{*}{ Follow-up } & \multirow[b]{2}{*}{ Age, years } & \multirow[b]{2}{*}{ Sex } & \multirow[b]{2}{*}{ Symptom } & \multicolumn{4}{|c|}{ Stratification with PPV $\geq 5 \%$} \\
\hline & & & & & & & Sex & Age, years & $\begin{array}{c}\text { Number wit } \\
\text { symptom }\end{array}$ & $\begin{array}{l}\text { PPV, } \\
\%(95 \% \mathrm{Cl})\end{array}$ \\
\hline \multirow{4}{*}{$\begin{array}{l}\text { Jones et al, } \\
2007^{12} \\
\text { (9 stars) }\end{array}$} & \multirow{4}{*}{$\begin{array}{l}\text { Retrospective } \\
\text { cohort }\end{array}$} & \multirow{4}{*}{$\begin{array}{l}\text { Routinely } \\
\text { recorded } \\
\text { mputer codes }\end{array}$} & \multirow{4}{*}{3 years } & \multirow[t]{4}{*}{$\geq 15$} & \multirow[t]{4}{*}{$\mathrm{M}+\mathrm{F}$} & \multirow{4}{*}{$\begin{array}{c}\text { Dysphagia } \\
\text { computer codes }\end{array}$} & \multirow[t]{4}{*}{ M } & $55-64$ & 518 & $6.0(4.1$ to 8.4$)$ \\
\hline & & & & & & & & $65-74$ & 576 & 9.0 (6.8 to 11.7$)$ \\
\hline & & & & & & & & $75-84$ & 476 & 7.1 (5.0 to 9.8$)$ \\
\hline & & & & & & & & $\geq 85$ & 154 & 9.7 (5.6 to 15.6$)$ \\
\hline $\begin{array}{l}\text { Esfandyari et al, } \\
2002^{33}\end{array}$ & $\begin{array}{c}\text { Prospective } \\
\text { cohort }\end{array}$ & $\begin{array}{l}\text { Specifically } \\
\text { registered }\end{array}$ & Not given & Not given & $\mathrm{M}+\mathrm{F}$ & Dysphagia & $\mathrm{M}+\mathrm{F}$ & $\begin{array}{l}\text { Not } \\
\text { given }\end{array}$ & 100 & 6.0 (2.8 to 12.5$)$ \\
\hline
\end{tabular}

(4 stars)

$F=$ female. $M=$ male. NOQAS $=$ Newcastle-Ottawa Quality Assessment Scales. $P P V=$ positive predictive value.

Table 9. Studies giving a PPV of $\geq 5 \%$ in one or more strata of symptoms for breast cancers.

\begin{tabular}{|c|c|c|c|c|c|c|c|c|c|c|}
\hline \multirow[b]{2}{*}{$\begin{array}{l}\text { Study and NOQAS } \\
\text { star rating }\end{array}$} & \multirow[b]{2}{*}{ Type } & \multirow[b]{2}{*}{$\begin{array}{c}\text { Data } \\
\text { source }\end{array}$} & \multirow[b]{2}{*}{ Follow-up } & \multirow[b]{2}{*}{ Age, years } & \multirow[b]{2}{*}{ Sex } & \multirow[b]{2}{*}{$\begin{array}{l}\text { Symptom } \\
\text { or sign }\end{array}$} & \multicolumn{4}{|c|}{ Stratification with PPV $\geq 5 \%$} \\
\hline & & & & & & & Sex & Age, years & $\begin{array}{r}\text { Number wit } \\
\text { symptom }\end{array}$ & $\begin{array}{c}\text { ith } \begin{array}{c}\text { PPV, } \\
\%(95 \% ~ C l)\end{array} \\
\end{array}$ \\
\hline $\begin{array}{l}\text { Eberl et al, } \\
2008^{34} \text { (5 stars) }\end{array}$ & $\begin{array}{c}\text { Retrospective } \\
\text { cohort }\end{array}$ & $\begin{array}{l}\text { Routinely } \\
\text { recorded data }\end{array}$ & Not given & Not given & $\mathrm{F}$ & $\begin{array}{c}\text { Breast lump/ } \\
\text { mass symptom }\end{array}$ & $\mathrm{F}$ & Not given & 741 & 8.1 (6.3 to 10.3$)$ \\
\hline $\begin{array}{l}\text { Barton et al, } \\
1999^{35} \text { (8 stars) }\end{array}$ & $\begin{array}{c}\text { Retrospective } \\
\text { cohort }\end{array}$ & $\begin{array}{l}\text { Routinely } \\
\text { recorded data }\end{array}$ & $1-11$ years & $40-69$ & $\mathrm{~F}$ & $\begin{array}{c}\text { Breast lump/ } \\
\text { mass symptom }\end{array}$ & $\mathrm{F}$ & $40-69$ & 196 & 10.7 (4.6 to 16.9 ) \\
\hline
\end{tabular}

$F=$ female. NOQAS = Newcastle-Ottawa Quality Assessment Scales. PPV = positive predictive value.

Table 10. Studies giving a PPV of $\geq 5 \%$ in one or more strata of symptoms for gynaecological cancer.

\begin{tabular}{|c|c|c|c|c|c|c|c|c|c|c|}
\hline \multirow[b]{2}{*}{$\begin{array}{l}\text { Study and NOQAS } \\
\text { star rating }\end{array}$} & \multirow[b]{2}{*}{ Type } & \multirow[b]{2}{*}{$\begin{array}{c}\text { Data } \\
\text { source }\end{array}$} & \multirow[b]{2}{*}{ Follow-up } & \multirow[b]{2}{*}{ Age, years } & \multirow[b]{2}{*}{ Sex } & \multirow[b]{2}{*}{$\begin{array}{l}\text { Symptom } \\
\text { or sign }\end{array}$} & \multicolumn{4}{|c|}{ Stratification with PPV $\geq 5 \%$} \\
\hline & & & & & & & Sex & Age, years & $\begin{array}{c}\text { Number with } \\
\text { symptom }\end{array}$ & $\begin{array}{c}\text { PPV, } \\
\%(95 \% \text { Cl) }\end{array}$ \\
\hline $\begin{array}{l}\text { Parker et al, } \\
2007^{13} \text { (7 stars) }\end{array}$ & $\begin{array}{l}\text { Retrospective } \\
\text { cohort }\end{array}$ & $\begin{array}{l}\text { Routinely } \\
\text { recorded } \\
\text { mputer codes }\end{array}$ & 2 years & $\geq 40$ & $\mathrm{~F}$ & $\begin{array}{c}\text { First ever } \\
\text { consultation with } \\
\text { postmenopausal } \\
\text { bleeding } \\
\text { computer codes }\end{array}$ & Female & $75-84$ & 856 & $5.4(4.7$ to 7.1$)$ \\
\hline
\end{tabular}

$F=$ female. NOQAS = Newcastle-Ottawa Quality Assessment Scales. PPV = positive predictive value. 
Table 11. Symptoms, signs and non-diagnostic tests in unselected primary care populations with a PPV of $\geq 5 \%$ for cancer for which there is robust evidence.

\begin{tabular}{|c|c|c|c|c|}
\hline Symptom & Cancer & Sex & Age, years & Evidence level for PPV of $5 \%$ or more in other cohorts \\
\hline $\begin{array}{l}\text { Rectal bleeding computer code or new } \\
\text { onset rectal bleeding }\end{array}$ & Colorectal & $\mathrm{M}+\mathrm{F}$ & $\geq 75$ & None aged $<60$ years, aged $60-74$ years equivocal \\
\hline Iron deficiency anaemia $\mathrm{Hb}<12 \mathrm{~g} / \mathrm{dl}$ & Colorectal & M & $\geq 60$ & \multirow{3}{*}{$\begin{array}{l}\text { Moderate evidence for gastrointestinal malignancy in men } \\
\text { with } \mathrm{Hb} \leq 12 \mathrm{~g} / \mathrm{dl} \text { aged }>20 \text { years and women with } \mathrm{Hb} \\
\leq 11 \mathrm{~g} / \mathrm{dl} \text { aged }>50 \text { years }\end{array}$} \\
\hline Iron deficiency anaemia $\mathrm{Hb}<11 \mathrm{~g} / \mathrm{dl}$ & Colorectal & $\mathrm{F}$ & $\geq 70$ & \\
\hline Iron deficiency anaemia $\mathrm{Hb}<9 \mathrm{~g} / \mathrm{dl}$ & Colorectal & $\mathrm{F}$ & $\geq 60$ & \\
\hline Haematuria & Urological & $\mathrm{M}+\mathrm{F}$ & $\geq 60$ & None aged $<40$ years, aged $40-60$ years equivocal \\
\hline Rectal examination malignant & Prostate & M & $\geq 40$ & No other evidence for PPV of $5 \%$ or more in other cohorts \\
\hline Haemoptysis computer code & Lung & M & $\geq 55$ & \multirow[t]{2}{*}{ No other evidence for PPV of $5 \%$ or more in other cohorts } \\
\hline Haemoptysis computer code & Lung & $\mathrm{F}$ & $\geq 65$ & \\
\hline Dysphagia computer code & Oesophagus & M & $\geq 55$ & No other evidence for PPV of $5 \%$ or more in other cohorts \\
\hline Breast lump or mass & Breast & $\mathrm{F}$ & $\geq 20$ & No other evidence for PPV of $5 \%$ or more in other cohorts \\
\hline Postmenopausal bleeding computer code & Gynaecological & $\mathrm{F}$ & $75-84$ & No other evidence for PPV of $5 \%$ or more in other cohorts \\
\hline
\end{tabular}

$F=$ female. $H b=$ haemoglobin. $M=$ male. $P P V=$ positive predictive value.

\section{DISCUSSION}

\section{Summary of main findings}

The study identified 21 papers that reported a PPV of $5 \%$ or more for a symptom, sign, or non-diagnostic test result alone or in combination in unselected primary care populations for cancer, and a further four studies reporting a PPV of less than $5 \%$ for the same symptom, sign, or non-diagnostic test result.

\section{Strengths and limitations of the review}

The definition of symptom differed between studies. In some, only the computer codes allocated to the consultation in the medical records were used, while others used the whole medical record including free text. The latter method will detect a greater number of patients with symptoms, as the computer code generally represents a summation of the consultation into a diagnosis or term representing patient management. This approach is encouraged in research practices (personal communication, Royal College of General Practitioners' [RCGP] Weekly Returns Service, 2010), with a stated preference for GPs to record diagnostic computer codes rather than symptom codes. It is unusual for a GP to record multiple history or symptom codes for a single problem. The studies that calculate PPVs for computer codes thus give values for patients in whom a GP is unable to make a more specific diagnosis. These studies do not give PPVs for symptoms presented to GPs, unlike studies in which free text is also analysed. Both types of study overestimate the PPV as a consequence of underrecording by GPs, especially when the clinician has a low level of suspicion for cancer. The size of this effect is not known. The PPVs will only remain valid if GP recording and patient consultation behaviour do not change with time.

A significant source of bias in studies using clinicians to specifically register a patient is selection of those with more severe symptoms and those in whom the clinician has a greater suspicion of malignancy. Such studies are considered to have a low weight in the present review of unselected primary care populations due to this selection bias, and are likely to overestimate the PPV. In the metaanalysis of rectal bleeding, there is a large degree of heterogeneity and a trend for the PPV to be lower in more recent studies. This partially reflects this source of bias and a change in recruitment methods over time from the use of specifically registered patients to routinely recorded data. In studies using computer codes, the actual codes used were not reported and may differ significantly between studies even when the symptom appears to be a single entity (personal communications, W Hamilton and $R$ Jones, 2009).

A recent systematic review and meta-analysis on studies that only involved the recruitment of cases of rectal bleeding by GPs commented on the difficulties of complete identification and follow-up of all incident cases of rectal bleeding in primary care and differences in age cut-off points between studies. ${ }^{38}$ The authors gave an estimated PPV of over $5 \%$ in those aged $\geq 60$ years with rectal bleeding.

Several other methodological problems can overestimate the PPV in studies, including the use of cancer registries resulting in the inclusion of cancers not diagnosed through primary care (for example, screen detected, referral within hospital, and admission via accident units), cancers diagnosed as an association and not the cause of symptoms, and recall bias in case-control studies.

Underestimation of the PPV may occur with inadequate follow-up, and the length of follow-up varied between studies from no follow-up to 11 years. The study by Jones et al indicates that 
some cancers are diagnosed 3 years after initial

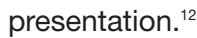

Other potential sources of bias in this review were that it only included English language papers, and that some papers in more specialist journals could not be located. This potential bias is unlikely to affect the results of the review, as, on closer examination of the abstracts, they are unlikely to have matched the study eligibility criteria.

The studies identified that calculated PPVs for combinations of symptoms, signs, or non-diagnostic test results and risk of cancer, involved populations that were too small and/or methods of recruitment that were subject to too high a risk of bias to draw firm conclusions. Three recent systematic reviews on the diagnostic utility of combinations of symptoms, signs, and test results for colorectal cancer showed that evidence in primary care is lacking, and when present only shows modest diagnostic value. ${ }^{38-40}$

A potential criticism of this review is that it only included symptoms, signs, and tests with a point estimate PPV of $5 \%$ or more. It is likely that it excluded good-quality studies with a point estimate of less than $5 \%$, but in which the $95 \%$ Cls included $5 \%$. It is possible that future research may identify additional symptoms, signs, and tests with a point estimate of $5 \%$ or more.

The level of risk an individual is prepared to take is specific to that person at that moment, and is dependent on many factors. Twenty-six additional studies were identified with PPVs of other symptoms, signs, and non-diagnostic test results for cancer of less than $5 \%$. A lower level of PPV than that used in this study will identify more symptoms, signs, and non-diagnostic test results for cancer, and additional age and sex groups in unselected primary care populations. Selecting a lower level of risk may diagnose cancer earlier in presenting populations but with the disadvantage that more individuals will undergo negative investigation with physical, psychological, and economic cost from the tests. A maximum level of risk for a population of $5 \%$ was chosen for this review, based on stated levels of risk in national guidelines concerning a comparable disease and treatment. The lower the level of risk, the greater the disagreement as to whether or not inaction can be justified.

When communicating with patients, it is preferable to use absolute measures of risk (number needed to investigate) rather than relative measures of risk. ${ }^{41}$ In assessing a patient's level of risk using predictive values, it is important to individualise the risk, as the PPV of the population will be modified by the individual's risk factors for the illness. There has been no debate with the public regarding what level of risk is acceptable..$^{14}$

\section{Implications for future research and clinical practice}

This study found evidence for only nine symptoms, signs, and non-diagnostic test results that have a high predictive value for cancer in patients presenting to GPs during routine consultations. A number of studies were subject to methodological and sample size difficulties, and for one symptom (change in bowel habit and colorectal cancer), high-quality studies using different methodology produced contradictory results. On the basis of good quality studies (with one or more studies on the quality-assessment tool at a level of 6 stars or more and no similar quality contradictory studies), broad consistency with published guidelines, ${ }^{4}$ and the unlikelihood that further research will change the conclusion of studies performed on large databases, it can be concluded that robust evidence exists for a PPV of $5 \%$ or more in specific age/sex groups as detailed in Table 11.

The low number of symptoms, signs, and nondiagnostic test results with a PPV of $5 \%$ or more was not unexpected, as the difficulties in diagnosing cancer in primary care have been commented on before. ${ }^{5}$ While these symptoms, signs, and nondiagnostic test results occur in the minority of patients with cancer, when they do occur, exclusion of cancer is obligatory unless exceptional circumstances exist. There is some evidence that GPs do not always act upon them. ${ }^{28,42,43}$ A previous effort to trigger GP action concerning one of the tests was unsuccessful, ${ }^{44}$ but this may have been due to the form of trigger used. The identified symptoms, signs, and non-diagnostic test results are broadly consistent with NICE recommendations for referral for suspected cancer. However, NICE generally uses a lower threshold for referral for additional symptoms and tests, and in the case of haemoptysis, even when the computer code is associated with a PPV of $5 \%$ or more.

The authors recommend research and development of general practice computer systems to produce effective warning flags when the symptoms, signs, or test results with a PPV of $5 \%$ or more from unselected primary care populations are entered for patients within the specified sex and age groups. The management of these patients should be audited and appraised. There is a need to standardise terms and analyses, and for further research on combinations of symptoms, signs, and non-diagnostic test results. There should be more open debate on the level of PPV that triggers a recommendation for referral by a GP.

\section{Funding body}

NHS North Staffordshire; NHS Stoke; NHS Executive West Midlands R\&D Office; North Staffordshire and Cheshire R\&D Consortium.

\section{Ethical approval}

Not applicable. 


\section{Competing interests}

The authors have stated that there are none.

\section{Acknowledgements}

We wish to thank Drs Judith Bell and Giri Rajaratnam Professor Peter Croft and Brian Dudley for commenting on the study design and draft paper.

\section{Discuss this article}

Contribute and read comments about this article on the Discussion Forum: http://www.rcgp.org.uk/bjgp-discuss

\section{REFERENCES}

1. Nexoe J, Halvorsen PA, Kistiansen IS. Critiques of the risk concept valid or not? Scand J Public Health 2007; 35(6): 648-654.

2. Loewenstein GF, Weber EU, Hsee CK, Welch N. Risks as feelings. Psychol Bull 2001; 127(2): 267-286.

3. Sackett DL, Strauss SE, Richardson WS, et al. Evidence-based medicine: how to practice and teach EBM. Edinburgh: ChurchillLivingston, 2000.

4. National Institute for Health and Clinical Excellence. Referral for suspected cancer: a clinical practice guideline. National Clinical Practice Guideline Number 27. London: National Institute for Health and Clinical Excellence, 2005.

5. Mulka O. NICE suspected cancer guidelines. Br J Gen Pract 2005; 55(517): 580-581.

6. National Institute for Health and Clinical Excellence. Cardiovascular risk assessment and the modification of blood lipids for the primary and secondary prevention of cardiovascular disease. National Clinical Practice Guideline Number 67. London: National Institute for Health and Clinical Excellence, 2009.

7. National Prescribing Centre. Statins: standard doses. Leeds: National Prescribing Centre, 2009.

http://www.npci.org.uk/therapeutics/cardio/cdlipids/resources/pda_L ipids.pdf. (accessed 20 Jul 2010)

8. Bowles CJA, Leicester R, Romaya C, et al. A prospective study of colonoscopy practice in the UK today: are we adequately prepared for national colorectal screening tomorrow? Gut 2004; 53(2): 277-283.

9. Wells GA, Shea B, O'Connell D, et al. The Newcastle-Ottawa Scale (NOS) for assessing the quality of nonrandomised studies in metaanalyses. Ottowa: Ottawa Health Research Institute. http://www.ohri.ca/programs/clinical_epidemiology/oxford.htm (accessed 20 Jul 2010).

10. Higgins JPT, Thompson SG, Deeks JJ, Altman DG. Measuring inconsistency in meta-analyses. BMJ 2003; 327(7414): 557-560.

11. Altman DG, Machin D, Bryant TN, Gardner MJ. Statistics with confidence. 2nd edn. London: BMJ Books, 2000.

12. Jones R, Latinovic R, Charlton J, Gulliford MC. Alarm symptoms in early diagnosis of cancer in primary care: cohort study using General Practice Research Database. BMJ 2007; 334(7602): 1040.

13. Parker C, Hippisley-Cox J, Coupland C, Vinogradova Y. Rectal and postmenopausal bleeding: consultation and referral of patients with and without severe mental health problems. Br J Gen Pract 2007; 57(538): 371-376.

14. Lawrenson R, Logie J, Marks C. Risk of colorectal cancer in genera practice patients presenting with rectal bleeding, change in bowel habit or anaemia. Eur J Cancer Care (Engl) 2006; 15(3): 267-271.

15. Wauters H, Van Casteren V, Buntinx F. Rectal bleeding and colorectal cancer in general practice: diagnostic study. BMJ 2000; 321(7267): 998-999.

16. Du Toit J, Hamilton W, Barraclough K. Risk in primary care of colorectal cancer from new onset rectal bleeding: 10 year prospective study. BMJ 2006; 333(7558): 69-70.

17. Heintze C, Matysiak-Klose D, Krohn T, et al. Diagnostic work-up of rectal bleeding in general practice. Br J Gen Pract 2005; 55(510): 14-19.

18. Ellis BG, Thompson MR. Factors identifying higher risk recta bleeding in general practice. Br J Gen Pract 2005; 55(521): 949-955.

19. Nørrelund N, Nørrelund H. Colorectal cancer and polyps in patient aged 40 years and over who consult a GP with rectal bleeding. Fam Pract 1996; 13(2): 160-165

20. Metcalf JV, Smith J, Jones R, Record CO. Incidence and causes of rectal bleeding in general practice as detected by colonoscopy. $\mathrm{Br} J$ Gen Pract 1996; 46(404): 161-164.

21. Fijten GH, Starmans R, Muris JW, et al. Predictive value of signs and symptoms for colorectal cancer in patients with rectal bleeding in general practice. Fam Pract 1995; 12(3): 279-286.

22. Mant A, Bokey EL, Chapuis PH, et al. Rectal bleeding: do other symptoms aid in diagnosis? Dis Colon Rectum 1989; 32(3): 191-196.

23. Hamilton W, Round A, Sharp D, Peters TJ. Clinical features of colorectal cancer before diagnosis: a population-based case-control study. Br J Cancer 2005; 93(4): 399-405.

24. Hamilton W, Lancashire R, Sharp D, et al. The risk of colorectal cancer with symptoms at different ages and between the sexes: a casecontrol study. BMC Med 2009; 7: 17.

25. Thompson JA, Pond CL, Ellis BG, et al. Rectal bleeding in general and hospital practice; the tip of the iceberg. Colorectal Dis 2000; 2(5): 288-293.

26. Leicester RJ, Colinjones DG, Hunt RH, et al. Hemoccult testing in general-practice for early diagnosis of colorectal-cancer. Gut 1984; 25(5): A561.

27. Stellon AJ, Kenwright SE. Iron deficiency anaemia in general practice: Presentations and investigations. Br J Clin Pract 1997; 51(2): 78-80.

28. Yates JM, Logan EC, Stewart RM. Iron deficiency anaemia in general practice: clinical outcomes over three years and factors influencing diagnostic investigations. Postgrad Med J 2004; 80(945): 405-410.

29. Hamilton W, Lancashire R, Sharp D, et al. The importance of anaemia in diagnosing colorectal cancer: a case-control study using electronic primary care records. Br J Cancer 2008; 98(2): 323-327.

30. Bruyninckx R, Buntinx F, Aertgeerts B, Van Casteren V. The diagnostic value of macroscopic haematuria for the diagnosis of urological cancer in general practice. Br J Gen Pract 2003; 53(486): $31-35$.

31. Hamilton W, Sharp DJ, Peters TJ, Round AP. Clinical features of prostate cancer before diagnosis: a population-based, case-control study. Br J Gen Pract 2006; 56(531): 756-762.

32. Hamilton W, Peters TJ, Round A, Sharp D. What are the clinical features of lung cancer before the diagnosis is made? A population based case-control study. Thorax 2005; 60(12): 1059-1065.

33. Esfandyari T, Potter JW, Vaezi MF. Dysphagia: a cost analysis of the diagnostic approach. Am J Gastroenterol 2002; 97(11): 2733-2737.

34. Eberl MM, Phillips RL Jr, Lamberts $\mathrm{H}$, et al. Characterizing breast symptoms in family practice. Ann Fam Med 2008; 6(6): 528-533.

35. Barton MB, Elmore JG, Fletcher SW. Breast symptoms among women enrolled in a Health Maintenance Organisation: frequency, evaluation, and outcome. Ann Intern Med 1999; 130(8): 651-657.

36. Bywaters JL. The incidence and management of female breast disease in a general practice. J R Coll Gen Pract 1977; 27(179): 353-357.

37. Office for National Statistics. Cancer statistics registrations. http://www.statistics.gov.uk/downloads/theme health/MB137/MB1_37_2006.pdf (accessed 20 Jul 2010).

38. Bekkink MO, McCowen C, Falk GA, et al. Diagnostic accuracy systematic review of rectal bleeding in combination with other symptoms, signs and tests in relation to cancer. Br J Cancer 2010; 102(1): 48-58.

39. Ford AC, Veldhuyzen van Zanten SJO, Rodgers CC, et al. Diagnosti utility of alarm features for colorectal cancer: Systematic review and meta-analysis. Gut 2008; 57(11): 1545-1552.

40. Jellema P, van der Windt DAWM, Bruinvels DJ, et al. Value of symptoms and additional diagnostic tests for colorectal cancer in primary care: systematic review and meta-analysis. BMJ 2010; 340: c1269.

41. Gigerenzer G, Edwards A. Simple tools for understanding risk: from innumeracy to insight. BMJ 2003; 327(7417): 741-744.

42. Edwards AGK, Robling MR, Wilkinson C, et al. The presentation and management of breast symptoms in general practice in South Wales. Br J Gen Pract 1999; 49(447): 811-812.

43. Newton P, Hannay D, Laver R. The presentation and management of female breast symptoms in general practice in Sheffield. Fam Pract 1999; 16(4): 360-365.

44. Logan ECM, Yates JM, Stewart RM, et al. Investigation and management of iron deficiency anaemia in general practice: a cluster randomised controlled trial of a simple management prompt. Postgrad Med J 2002; 78(923): 533-537. 